\title{
The Influence of Principal Leadership toward Teacher Performance: A Literature Review
}

\author{
Muhammad Arif Mustaqim ${ }^{1}$, Alifa Soraya Nuryadika ${ }^{2}$, Veronica Eka Desi Natalia ${ }^{3}$, Sowiyah $^{4}$ \\ ${ }^{1,2,3}$ Student of Education Administration, University of Lampung, Lampung, Indonesia \\ ${ }^{4}$ Lecture of Education Administration, University of Lampung, Lampung, Indonesia
}

\begin{abstract}
The objectives of this research were to examine the Influence of Principal Leadership toward Teacher Performance. This research consists of independent variables (Principal Leadership) and the dependent variable (Teacher performance). This research was used a qualitative descriptive method by Literature Review. Data collected by a search engine, google scholar, to search the articles with keywords. Principal's leadership and teacher performance. Based on the results of the literature review we found that there is the influence of principal leadership toward teacher performance across various countries, in general, it can be concluded that there is the influence of principal leadership toward teacher performance.
\end{abstract}

KEYWORDS: Principal Leadership, Teacher Performance, Literature Review

\section{INTRODUCTION}

School is a formal educational institution that organizes teaching and learning activities to achieve educational goals. Good quality education is created from certified educators as well. One of the strategies that can be achieved to improve the fine of graduates is by way of improving the educating performance of the educators. (Murtiningsih, Kristiawan, \& Lian, 2019). Teacher performance is a very important factor in determining quality in the learning process and the quality of education because the implications affect the quality of graduates (Kusrini, Suriansyah, \& Saleh, 2018). Only teachers who have good quality and a strong commitment to being able to produce quality students. Therefore, teachers must continue to improve the quality and expertise of their knowledge. (Tehseen \& Hadi, 2015). Some of the principals' efforts that can be done to improve the quality of teacher performance areas giving awards to outstanding teachers, giving incentives beyond their salaries, carrying out teacher training, and conducting mentoring and evaluation (Andriani, Kesumawati, \& Kristiawan, 2018).

Performance is the result or level of success achieved by someone in their work environment according to criteria evaluated by certain people, especially the employer concerned. Teacher Performance is the ability and effort of teachers to carry out learning tasks as well as possible in planning teaching programs, implementing learning activities, and evaluating learning outcomes. Teacher performance achieved must be based on professional ability standards while carrying out obligations as teachers in schools (Rachmawati, 2013).

Many factors affect teacher performance, both internal and external factors. Internal factors such as work motivation and competence of the teacher itself, while external factors include the work environment and family environment. Other factors that can improve teacher performance are the principal's leadership, school climate, and teacher professional allowances. The principal is one component of education that affects improving teacher performance. As a leader, the principal is responsible for organizing educational activities that occur in the school he leads. The principal's leadership ability is one of the determining factors in improving teacher performance by empowering teachers to improve their performance abilities. (Yaman, 2020)

The principal is the highest leader in the school, the principal has a role in developing the quality of education in his school (Rosida, 2019). The success of education in schools is largely determined by the principal's how to manage the teachers available at his school (Lee \& Li, 2015). The principal as a leader must be able to influence, motivate, and be able to provide a sense of comfort to the teacher, so that the teacher can optimally carry out his tasks wholeheartedly without any compulsion (Li, Hallinger, \& Walker, 2016). So it is not surprising that the effectiveness of a teacher's performance can increase, because of the influence of the principal by giving support to them. (Stein, Macaluso, \& Stanulis, 2016)

Regarding this matter, it has been found out that some researchers have examined the Effect of Principal Leadership on Teacher Performance in various Countries such as Indonesia (Rachmawati, 2013), (Fatmawati, 2017), (Andriani et al., 2018); Turkey (Aydin, 


\section{International Journal of Current Science Research and Review}

ISSN: 2581-8341

Volume 04 Issue 04 April 2021

DOI: 10.47191/ijcsrr/V4-i4-10, Impact Factor: 5.825

Sarier, \& Uysal, 2013); hong kong (Li et al., 2016); Also, Rachmawati (Rachmawati, 2013) has also conducted a study on the effect of Principal Leadership on Teacher Performance, but the conclusion is limited to the influence of school principal leadership toward teacher performance at one school in Indonesia. Therefore, this study is a meta-analytical research question that guides this paper's focus: What is the Influence of Principal Leadership toward Teacher Performance base on a literature review?

\section{METHOD}

This literature review focuses on principals' leadership and Teacher Performance. The review process begins with a search engine, google scholar, to search the articles with keywords. "Principal's Leadership and Teacher Performance". The criteria for inclusion in this study are as follows:

a. Qualitative and quantitative results of the principal's leadership and Teacher Performance.

b. The research was conducted in world

c. The research used English and Indonesian language

d. Dissertation and thesis are excluded.

\section{RESULT AND DISCUSSION}

This literature review focus on the influence of principal leadership on teacher performance. This research consists of independent variables (Principal Leadership) and the dependent variable (Teacher performance). The results of the literature review presented in Table 1 below.

Table 1. The Influence of Principal Leadership toward Teacher Performance

\begin{tabular}{|c|c|c|c|c|c|}
\hline $\begin{array}{l}\text { Author and } \\
\text { Year }\end{array}$ & & Title & Country & Method & Results \\
\hline $\begin{array}{l}\text { Utami, } \\
\text { Latiana, } \\
\text { Pranoto } \\
(2019)\end{array}$ & $\&$ & $\begin{array}{l}\text { A Study on the Influence } \\
\text { of Personality and Social } \\
\text { Competencies on the } \\
\text { Performance of } \\
\text { Kindergarten Teachers } \\
\text { Based on the Principal's } \\
\text { Assessment }\end{array}$ & Indonesia & Quantitative & $\begin{array}{l}\text { First, there was a positive and significant } \\
\text { influence between personality competences } \\
\text { toward teacher performance with a significance } \\
\text { of } 41.8 \% \text {. Second, there was a positive and } \\
\text { significant influence between social } \\
\text { competences toward teacher performance with a } \\
\text { significant percentage of } 47.8 \% \text {. Third, there was } \\
\text { a positive and significant influence between } \\
\text { personality and social competencies toward } \\
\text { teacher performance with a significant } \\
\text { percentage of } 51.9 \% \text {. }\end{array}$ \\
\hline $\begin{array}{l}\text { Darmawati, } \\
\text { Munjin, } \\
\text { Seran } \\
(2015)\end{array}$ & $\&$ & $\begin{array}{l}\text { Effect Of Supervision of } \\
\text { Principal Teacher } \\
\text { Performance in SMPN } 1 \\
\text { Parung Bogor }\end{array}$ & Indonesia & Associative & $\begin{array}{l}\text { The research conclusion showed that the } \\
\text { influence of principal supervising toward teacher } \\
\text { performance by } 19.5 \% \text { and the remaining } 80.5 \% \\
\text { was determined other factors, such as the } \\
\text { assessment of teachers by students, delivery of } \\
\text { teaching material according to the students } \\
\text { opinion, incentives, teacher certification. }\end{array}$ \\
\hline $\begin{array}{l}\text { Player, } \\
\text { Youngs, } \\
\text { Perrone, } \\
\text { Grogan } \\
\text { (2017) }\end{array}$ & $\&$ & $\begin{array}{l}\text { How Principal } \\
\text { Leadership and Person- } \\
\text { Job Fit are Associated } \\
\text { with Teacher Mobility } \\
\text { and Attrition }\end{array}$ & USA & Quantitative & $\begin{array}{l}\text { Leadership and P-J fit predict retention in one's } \\
\text { school and retention in the teaching profession, } \\
\text { respectively, and we find no evidence that these } \\
\text { associations are moderated by school or teacher } \\
\text { characteristics. }\end{array}$ \\
\hline
\end{tabular}




\section{International Journal of Current Science Research and Review}

ISSN: 2581-8341

Volume 04 Issue 04 April 2021

DOI: 10.47191/ijesrr/V4-i4-10, Impact Factor: 5.825

IJCSRR@ 2021

Www.ijcsrr.org

\begin{tabular}{llrll}
\hline $\begin{array}{l}\text { Adenike } \\
(2011)\end{array}$ & Organizational Climate & Nigeria & Quantitative & The study provides insight into organizational \\
& as a Predictor of & factors that impinge on job satisfaction in a \\
& Employee & Job & privatized environment using private university \\
& Satisfaction: Evidence & (in the South-West Nigeria) as sample area. \\
& from & Covenant &
\end{tabular}

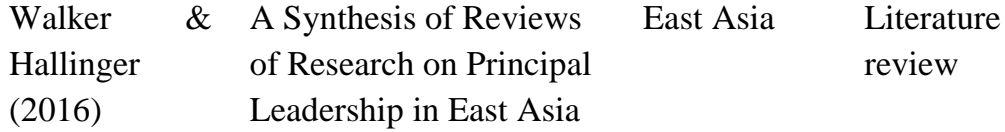

Marks \& Principal Leadership and

Printy School Performance: An

(2003) Integration of

Wills

(2016)

Hallinger

\& Walker

(2015)

Macaluso, \& Principal Leadership and

Stanulis

(2016)

Dou, Devos, The

\& Valcke

(2017)
Transformational and

Instructional Leadership

The Interplay Between

Teacher Leader Efficacy

Principal leadership

changes and their consequences for school performance in South Africa

(n) principal leadership and teacher professional learning in Hong Kong primary schools

USA

South Africa Quantitative

Hongkong

Quantitative

USA

Qualitative

The

Relationships

Between

School

Autonomy Gap, Principal

Leadership, Teachers'

Job Satisfaction and

Quantitative

Qualitative
Transformational leadership is a necessary but insufficient condition for instructional leadership. When transformational and shared instructional leadership coexist in an integrated form of leadership, the influence on school performance, measured by the quality of its pedagogy and the achievement of its students, is substantial.

School fixed effects and propensity score matching with difference-in-difference estimations confirm that principal changes are indeed detrimental to school performance with larger disruptive effects observed in poorer schools.

To compensate weaknesses of the orthodox regression based approach, significance of the mediating effects of trust were tested using the Sobel's test and bootstrapping method. Next, the seven core sets of principal leadership practices were used as multiple predictors, and mediating effects of trust between them and teacher professional learning were also examined.

Teacher leader efficacy is rooted both in the teacher leaders' self-perceptions and in how those perceptions influence and are influenced by principals' expectations and leadership behaviors. transformational leadership on teachers' job satisfaction and organizational commitment, mediated by the indirect impact of school climate and teachers' self-efficacy. School autonomy 
ISSN: 2581-8341

Volume 04 Issue 04 April 2021

DOI: 10.47191/ijcsrr/V4-i4-10, Impact Factor: 5.825

\begin{tabular}{|c|c|c|c|}
\hline & $\begin{array}{l}\text { Organizational } \\
\text { Commitment }\end{array}$ & & \\
\hline $\begin{array}{l}\text { Istiqomah, } \\
\text { Ekosiswoyo, } \\
\text { \& Pramono } \\
(2019)\end{array}$ & $\begin{array}{lr}\text { Influence of } & \text { School } \\
\text { Culture, Headmaster } \\
\text { Supervision }\end{array}$ & Indonesia & Quantitative \\
\hline
\end{tabular}

Lee \& Li (2015)

Murtiningsih Kristiawan, \& Lian (2019)
Principal Leadership and

Its Link to the Development of a School's Teacher Culture and Teaching Effectiveness: A Case Study of an AwardWinning Teaching Team at an Elementary School
Taiwan

Qualitative

Quantitative

Supervision of

Headmaster

and

Interpersonal

Communication with

Work Ethos of The

Teacher gap, which is closely related to principal leadership, emerged as an important influence in the path model.

Teacher social behavior tends to be influenced by school culture than headmaster supervision. Meanwhile, interpersonal communication skill is not an intervening variable that influence others variable relation. The number of factors that give influence on teacher social behavior other than research variables, the researcher suggests that the stakeholder (teacher, headmaster and school) should uphold character value implementation in every school activity.

1) The award-winning teacher group at the school was able to facilitate the development of professional co-operation and teaching innovation within the school and to transform the school into a learning community; 2) The campus ethics of affiliation, collegiality, and experience-heritage were cultivated at the award-winning elementary school; 3) The school leaders, especially the principal, had a critical impact on the development of the school's teacher culture via their determination and encouragement; and 4) Both the school principal and the school's senior teachers played an exemplary and leading role in shaping a high quality school culture for professional development.

There is a significant correlation between Principal Supervision (X1) and Teacher Working Ethics (Y) or it can be interpreted that $\mathrm{Ho}$ is rejected and $\mathrm{Ha}$ accepted so that the hypothesis says that "Principal Supervision relates to Teacher Working Ethics SMP Ilir Barat II Palembang is significant. There is a significant relationship between Interpersonal Communication (X2) with Teacher Working Ethics or it can be interpreted that Ho is rejected and $\mathrm{Ha}$ accepted so that the hypothesis that Interpersonal Communication with Teacher Working Ethics of SMP Ilir Barat II Palembang is significant.

(1) headmaster managerial ability has a positive
Fatmawati (2016)
The Effect
Headmaster's

Managerial

and

Supervision Abilities impact on increasing the performance of teachers; (2) the role and supervision of learning in order to improve the performance of teachers

Quantitative in order to improve the performance of teachers 


\section{International Journal of Current Science Research and Review}

ISSN: 2581-8341

Volume 04 Issue 04 April 2021

DOI: 10.47191/ijcsrr/V4-i4-10, Impact Factor: 5.825

IJCSRR@ 2021

Www.ijcsrr.org

\begin{tabular}{|c|c|c|c|c|}
\hline & $\begin{array}{l}\text { Towards } \\
\text { Performance of Junior } \\
\text { High School at Muna } \\
\text { Barat and Muna in South } \\
\text { East of Sulawesi }\end{array}$ & & & $\begin{array}{l}\text { in Junior High School at Muna and Muna Barat } \\
\text { in South East of Sulawesi still not quite optimal; } \\
\text { and (3) performance of teachers at the Junior } \\
\text { high School in Muna and Muna Barat classified } \\
\text { in high category. }\end{array}$ \\
\hline $\begin{array}{l}\text { Yulia } \\
\text { Rachmawati } \\
(2013)\end{array}$ & $\begin{array}{l}\text { The Effect of Principal } \\
\text { Leadership on Teacher } \\
\text { Performance of } \\
\text { Vocational High School } \\
\text { Sandikta Bekasi }\end{array}$ & Indonesia & Quantitative & $\begin{array}{l}\text { (1) There is a significant influence of the } \\
\text { principal's leadership on the performance of the } \\
\text { teachers of Vocational High School } \\
\text { Sandikta Bekasi. (2) F test results obtained } \\
\text { Fcount = } 10.037 \text { with a sig }=0.03<0.05 \text {, it can } \\
\text { be concluded that Ho is rejected. This suggests } \\
\text { that there is an influence of the principal's } \\
\text { leadership on teacher performance. (3) Based on } \\
\text { the research results, it shows that there is an } \\
\text { influence of the principal's leadership on teacher } \\
\text { performance by } 15.1 \% \text {, while the rest is } \\
\text { influenced by other factors. (4) As a leader the } \\
\text { principal has a duty to mobilize all existing } \\
\text { resources in school so that they can be } \\
\text { empowered to be used optimally in order to } \\
\text { achieve predetermined goals. Whether or not the } \\
\text { performance of teachers in school really depends } \\
\text { on how the principal's ability to influence teacher } \\
\text { behavior in carrying out their duties.(5) In } \\
\text { carrying out their duties, teachers tend to submit } \\
\text { to the principal so that everything that is carried } \\
\text { out by the teacher must refer to the policies of the } \\
\text { school principal. In addition, if there are } \\
\text { deviations in the implementation of the policy, } \\
\text { the principal has the right to admonish or give } \\
\text { warnings. }\end{array}$ \\
\hline
\end{tabular}

This section reports the main findings of the reviewed articles. Analysis shows that most articles focus effect and influence of principal leadership on teacher performance. Articles that have been reviewed are those in which research was conducted in the world. Conducting research has been carried out in schools.

Based on the reviewed articles in the table above shows that the research has been carried out in various countries. Based on the results of literature reviews and reviews from sources obtained, the analysis shows that the principal's leadership is one of the important components that determine how the teacher's performance. It means that teacher performance can be influenced by the principal's leadership in the place where he teaches.

First, there was a positive and significant influence between personality competence toward teacher performance. Second, there was a positive and significant influence between social competence toward teacher performance. Third, there was a positive and significant influence between personality and social competencies toward teacher performance (Utami, Latiana, \& Pranoto, 2019). The influence of school principal supervision on teacher performance is $19.5 \%$ and the remaining $80.5 \%$ is determined by other factors, such as teacher assessment by students, delivery of teaching materials according to student opinions, incentives, teacher certification (Darmawati, Munjin, \& Seran, 2015). It means that principal supervision is one factor in determining teacher performance and several other factors. 


\title{
International Journal of Current Science Research and Review
}

ISSN: 2581-8341

\author{
Volume 04 Issue 04 April 2021 \\ DOI: 10.47191/ijcsrr/V4-i4-10, Impact Factor: 5.825 \\ IJCSRR@ 2021
}

WWW.ijcsrr.org

\section{CONCLUSION}

However, because almost all research results show that there is the influence of principal leadership toward teacher performance across various countries, in general, it can be concluded that there is the influence of principal leadership toward teacher performance. Teacher performance is important in education. Good performance by teachers will have a positive impact on school quality. Many factors affect teacher performance, one is the principal's leadership. The broad conclusion is that when we consider all the reviews about the influence of principal leadership toward teacher performance that was conducted in the world, there is the relationship between both variables.

\section{REFERENCES}

1. Adenike, A. (2011). Organizational Climate as a Predictor of Employee Job Satisfaction: Evidence from Covenant University Business Intelligence Journal.

2. Andriani, S., Kesumawati, N., \& Kristiawan, M. (2018). The Influence Of The Transformational Leadership And Work Motivation On Teachers Performance. International Journal of Scientific \& Technology Research, 7 (7).

3. Aydin, A., Sarier, Y., \& Uysal, S. (2013). The Effect of School Principals' Leadership Styles on Teachers' Organizational Commitment and Job Satisfaction. Educational sciences: Theory and practice, 13 (2), 806 - 811.

4. Darmawati, Munjin, R. A., \& Seran, G. G. (2015). Effect Of Supervision Of Principal Teacher Performance In SMPN 1 Parung Distric Parung Bogor. Jurnal Governansi ISSN 2442 - 3971 Volume 1 Nomor 1

5. Dou, D., Devos, G., \& Valcke, M. (2017). The relationships between school autonomy gap, principal leadership, teachers' job satisfaction and organizational commitment. Educational Management Administration \& Leadership, 45 (6). doi:10.1177/1741143216653975

6. Fatmawati, W. O. (2017). The Effect of Headmaster's Managerial and Supervision Abilities Towards Teachers Performance of Junior High School at Muna Barat and Muna in South Eastof Sulawesi. Paper presented at the International Conference on Education (ICE2) 2018: Education and Innovation in Science in the Digital Era.

7. Istiqomah, D. N., Ekosiswoyo, R., \& Pramono, S. E. (2019). Influence of School Culture, Headmaster Supervision and Interpersonal Communication Towards Teacher's Social Behavior. Educational Management.

8. Kusrini, L., Suriansyah, A., \& Saleh, M. (2018). The Influence Of Supervision Of Academic Supervisor With Commitment And Work Motivation On Performance Of Teachers Of The State High School In Banjarmasin, Indonesia. European Journal of Education Studies. doi:10.5281/zenodo.1494160

9. Lee, H.-H., \& Li, M.-n. F. (2015). Principal Leadership and Its Link to the Development of a School's Teacher Culture and Teaching Effectiveness: A Case Study of an Award-Winning Teaching Team at an Elementary School. International Journal of Education Policy and Leadership, 10 (4).

10. Li, L., Hallinger, P., \& Walker, A. (2016). Exploring the mediating effects of trust on principal leadership and teacher professional learning in Hong Kong primary schools. Educational Management Administration \& Leadership, 44 (1). doi:10.1177/1741143214558577

11. Marks, H. M., \& Printy, S. M. (2013). Principal leadership and school performance: An integration of transformational and instructional leadership. Educational administration quarterly, 39 (3). doi:10.1177/0013161X03253412

12. Murtiningsih, Kristiawan, M., \& Lian, B. (2019). The Correlation Between Supervision Of Headmaster And Interpersonal Communication With Work Ethos Of The Teacher. European Journal of Education Studies, 6 (1). doi:10.5281/zenodo.2649535

13. Player, D., Youngs, P., Perrone, F., \& Grogan, E. (2017). How Principal Leadership And Person-Job Fit Are Associated With Tacher Mobility And Attrition. Teaching and Teacher Education.

14. Rachmawati, Y. (2013). Pengaruh Kepemimpinan Kepala Sekolah Terhadap Kinerja Guru. Ekonomi IKIP Veteran Semarang, 1 (2).

15. Rosida, I. (2019). Kepemimpinan Kepala Sekolah Terhadap Kinerja Guru Di Smp Negeri Wilayah Petir Serang-Banten. Faktor Jurnal Ilmiah Kependidikan, 6.

16. Stein, K. C., Macaluso, M., \& Stanulis, R. N. (2016). The interplay between principal leadership and teacher leader efficacy. Journal of School Leadership, 26 (6). doi:10.1177/105268461602600605 


\section{International Journal of Current Science Research and Review}

ISSN: 2581-8341

Volume 04 Issue 04 April 2021

DOI: 10.47191/ijcsrr/V4-i4-10, Impact Factor: 5.825

IJCSRR@ 2021

Www.ijcsrr.org

17. Tehseen, S., \& Hadi, N. U. (2015). Factors influencing teachers' performance and retention. Mediterranean Journal of Social Sciences, 6 (1), 233. doi:10.5901/mjss.2015.v6n1p233

18. Utami, D. R. F., Latiana, L., Kurniawati, Y., \& Pranoto, S. (2019). A Study on the Influence of Personality and Social Competencies on the Performance of Kindergarten Teachers Based on the Principal's Assessment. Journal of Primary Education 11 (1). doi:doi.org/10.15294/jpe.v11i3.36057

19. Walker, A., \& Hallinger, P. (2016). A synthesis of reviews of research on principal leadership in East Asia. Journal of Educational Administration, 53 (4). doi:10.1108/JEA-05-2015-0038

20. Wills, G. (2016). Principal leadership changes and their consequences for school performance in South Africa. International Journal of Educational Development, 51. doi:10.1016/j.ijedudev.2016.08.005

Cite this Article: Muhammad Arif Mustaqim, Alifa Soraya Nuryadika, Veronica Eka Desi Natalia, Sowiyah (2021). The Influence of Principal Leadership toward Teacher Performance: A Literature Review. International Journal of Current Science Research and Review, 4(4), 317-323 